\title{
Synthesis and Characterization of Colistin Loaded Nanoparticles Used to Combat Multi-drug Resistant Microorganisms
}

\author{
DANIELA LUMINITA ICHIM ${ }^{1,4}$, LETITIA DOINA DUCEAC1,5*, CONSTANTIN MARCU2,6*, ALIN CONSTANTIN IORDACHE 3,7*, \\ IRINA MIHAELA CIOMAGA 3,5 , ALINA COSTINA LUCA ${ }^{3,5}$, ELENA ROXANA BOGDAN GOROFTEI ${ }^{2,8}$, GETA MITREA, \\ DANIELA DAMIR ${ }^{3}$, LIVIU STAFIE ${ }^{1,10}$ \\ ${ }^{1}$ Faculty of Medicine, Apollonia University of lasi, 2 Muzicii Str., Iasi, Romania \\ 2 University Dunarea de Jos Faculty of Medicine and Pharmacy, 47 Domneasca Str., 800008, Galati, Romania \\ ${ }^{3}$ Grigore T. Popa University of Medicine and Pharmacy of lasi, 16 Universitatii Str., 700115, Iasi,Romania \\ ${ }^{4}$ Dr. Iacob Czihac Military Emergency Clinical Hospital, 9 Henri Berthelot, 700483. Iasi, Romania \\ ${ }^{5}$ Sf. Maria Clinical Emergency Hospital for Children, 62 Vasile Lupu Str., 700309, Iasi, Romania \\ ${ }^{6}$ Saarbrucken- Caritasklink St. Theresia University Hospital, Germany \\ ${ }^{7}$ Nicolae Oblu Neurosurgery Hospital of lasi, 2 Ateneului Str., 700309, Iasi, Romania \\ 8Sf. Ioan Emergency Clinical Hospital for Children, 2 Gheorghe Asachi Str., 800578, Galati, Romania \\ ${ }^{9} \mathrm{Sf}$. Ap. Andrei Emergency Clinical Hospital, 177 Brailei Str., 800578, Galati, Romania \\ ${ }^{10}$ Public Health Directorate of Iasi, 2-4 Vasile Conta, 7001016, Iasi, Romania
}

\begin{abstract}
Some infectious agents frequently act on human body. Multi-drug resistantmicroorganisms (MDR) develop the capacity to stabilize biofilms. The use of antimicrobials loaded nanoparticles can defeat antibiotic resistance mechanism. The major aim of this study was the synthesis and physico-chemical characterization of Colistin molecules intercalated nanoparticles in order to enhance antibiotic efficacy against multi-drug resistant microorganisms. Advanced characterization techniques were used to analyze new nanostructures containing antibiotics in order to improve antimicrobial efficacy of the free drug. Nano-encapsulated Colistin is presumed to be more efficient in the eradication of severe infections caused by MDR.
\end{abstract}

Keywords: nanoparticles, Colistin, infection, sepsis, pediatrics, epidemiology, neurosurgery, cardiology, pulmonology.

Colistin is an antibiotic possessing a bactericidal effect against Gram (-) bacteria being used since 1950s. Yet, plenty of side effects such as nephrotoxicity and neurotoxicity effect and the existence of safer alternatives limited the drug administration. Although the usage of this antibiotic was interdicted for many years due to its severe toxicities, it was reintroduced again due to occurrence of multi-drug resistant (MDR) microorganisms. These pathogens strength is expressed as microorganism resistance to at least three groups of antibiotic molecules with peculiar activity against Gram (-) bacteria. This stringent issue of antibiotic resistance and the low rate of new drugs development generated reconsideration of Colistin usage [1-6].

Nosocomial infections caused by MDR infectious agents increased remarkably representing at the moment a common global problem being a real problem for epidemiology field. There are incoming threats to current medicine from the appearance of MDR causing healthcare associated infections to people having immunitar" deficiencies of all ages from prematures, new borne pregnant, confinement after birth to young and old peopl respectively..

Sepsis is a worldwide healthcare matter and a bi challenge that healthcare specialists deals with. In la! few years, it became a major cause of death and it incidence increased risk of developing antimicrobic resistance [7-21]. Antimicrobial treatment must $b$ administrated when sepsis is suspected. Sites involvin sepsis are respiratory tract, genitourinary tract abdomer soft tissue infections, injuries, the central nervous syster and the cardiovascular system concerning differer specialists in pediatrics, neurosurgery, cardiology anu especially pulmonology areas. Even in some cases the source is unknown, most of pathogens depend on infection area [22-26].

Many countries use in clinical practice antibiotics such as penicillin, aminoglycoside, quinolone, cephalosporin and carbapenem for Gram (-) bacterial infection treatment. Increased prevalence regarding Gram (-) bacteria resistance against novel antibiotic including carbapenem was reported mostly in developed countries. The interest for old antibiotic polymixins was reopened as saving therapy in the management of infection caused by MDR pathogen agents including Pseudomonas, Klebsiella, Acinetobacter and Enterobacter species. Polymyxins represent a group of cationic polypeptide antibiotics with five different compounds namely polymyxin $A-E$, Colistin being denoted as pylymyxin $E$ in figure 1 . It is a multicomponent antibiotic mixture, the two important constituents of which are Colistin A and Colistin B with one carbon included in the fatty acyl chain distinguishing the two components.

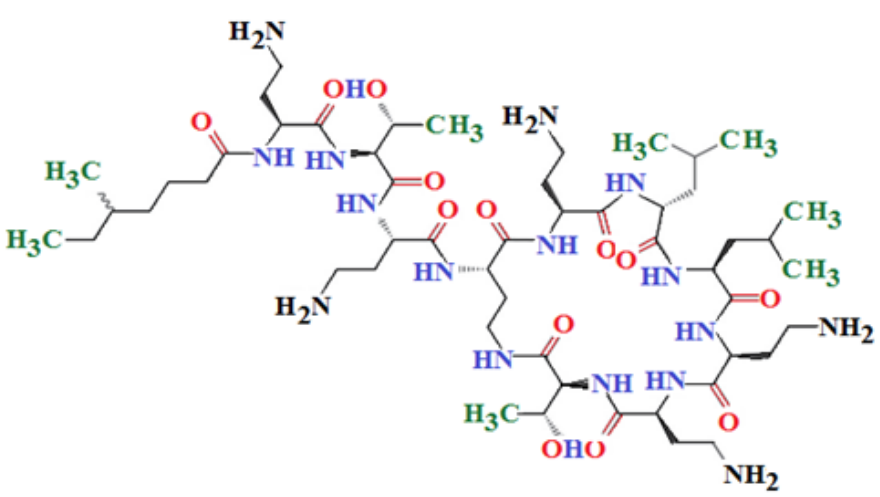

Fig. 1. Chemical structures of colistin 
This drug has very good bactericidal activity against most Gram (-) bacilli and no activity against all Gram (+) and most anaerobes. The action site of Colistin is lipopolysaccharide constituent of the external membrane of gram-negative bacteria. In there, the antibiotic molecules interact with the lipid A component of the lipopolysaccharide displacing magnesium and calcium bridges, thus making the bacterial outer membrane permeable. Subsequently, drug molecules entered through the created cracks cause self-promoted uptake followed by the disintegration of the inner membrane, hence causing bacterial killing [27-32].

Recent evidence refers to the risk implying Colistin mono-therapy mentioning that combined therapy should be taken into account for clinical usage in terms of efficacy and preventing resistance evolution. Knowing that second antibiotics like meropenem in combination with Colistin for an efficient infections treatment, differ physicchemically and bio-pharmaceutically from Colistin, a novel antibiotic delivery system able to sustain drug release needs to be explored. Thus, liposomes are promising delivery carriers for the new formulation meaning antibiotic intercalated nanoparticles. These compounds yield many advantages by maintaining local antibiotic concentration above their minimum inhibitorylevels conducting to a more efficient therapy [33-36]. Antibiotic molecules encapsulated liposomes exhibit synergistic effect against Gram (-) bacteria beyond the activity of antibiotic alone. Liposomes can be designed to intercalate drug and merge with bacterial cells delivering their payload directly to the targeted cells. These new nanostructures type Colistinliposomes maximize the administration of antibiotic by exhibiting superior penetration into biofilm and by controlling the release of the drug [37-41].

\section{Experimental part}

\section{Materials and methods}

Preparation of Colistin loaded liposomes by dry film method

For liposomes preparation by dry film method, $500 \mathrm{mg}$ of dioleoylphosphatidylcholine (DOPC) was dissolved in $1.5 \mathrm{~mL}$ of chloroform:methanol (in a volume ratio of $2: 1$ ) with cholesterol at a molar ratio of 2:1 DOPC : cholesterol. Then, the solvent was eliminated under vacuum using a rotary evaporation and the dry lipid film was washed using a continuous stream of nitrogen gas in order to remove trace solvent.

The obtained dry film was dispersed in $10 \mathrm{~mL}$ of Colistin solution and stirred until the lipid was entirely dispersed.

Empty liposomes were obtained by hydration of the lipid film with ultrapure water. Finally, liposomes were sonicated for 15 min on a cooled water bath.

Preparation of Colistin loaded liposomes by freeze-drying method

Freeze-drying method using t-butanol cosolvent system was used to prepare liposomes containing Colistin. 200 $\mathrm{mg}$ of DOPC were dissolved in $5 \mathrm{~mL}$ t-butanol to prepare phase A. Phase B was prepared by dissolution of Colistin in $15 \mathrm{~mL}$ water containing $100 \mathrm{mg} / \mathrm{mL}$ sucrose. Then, $10 \mathrm{~mL}$ of phase $B$ was added to phase $A$ and shaked until clear. The obtained product was iced at $-80^{\circ} \mathrm{C}$ for 8 hours then loaded into a freeze drier with a shelf temperature of $40^{\circ} \mathrm{C}$. This step was carried out for 48 hours succeeded by a drying step at $25^{\circ} \mathrm{C}$ for $24 \mathrm{~h}$.

After synthesis of nanoparticles, advanced characterization techniques were used in order to determine their physical-chemical properties.

\section{Results and discussions}

Zeta potential of liposomes prepared with increasing concentrations of Colistin is presented in figure 2 . The liposomes assumed the predicted charge from cationic Colistin, denoting direct association of the direct coalition of the amphiphilic lipopeptide with the liposome nanostructure.

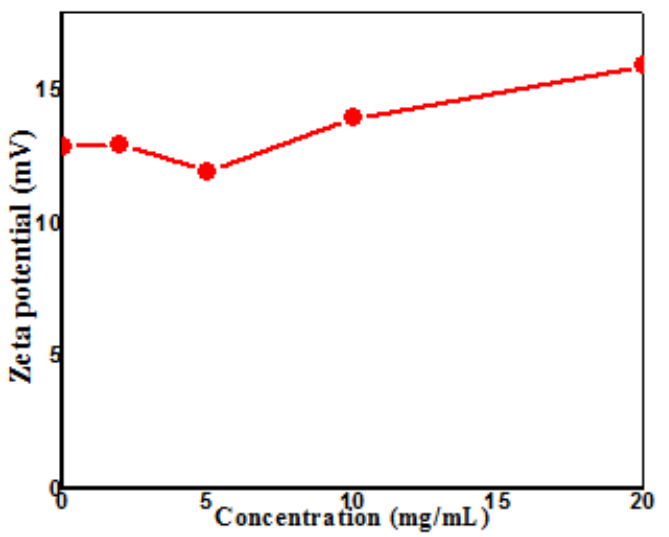

Fig. 2. Zeta potential of liposomes loaded with Colistin

Increasing Colistin concentration did not had as consequence a linear increase in surface charge.

Particle size distribution of the as prepared nanostructures showed an average particle size for Colistinloaded liposomes of approximately $180 \mathrm{~nm}$ across the range of Colistin concentrations in the dispersion.

Particle size stable is over the full 7 day storage period in the presence of Colistin, with no alteration in surface charge over time for Colistin encapsulated liposomes.

There was no modification in surface charge over time for Colistin-loaded liposomes.

By dry film method and freeze-drying of liposome preparation were obtained liposomes with similar zaverage size and size distribution with diameters around $190 \mathrm{~nm}$ and $160 \mathrm{~nm}$ respectively, as presented in figure 3.

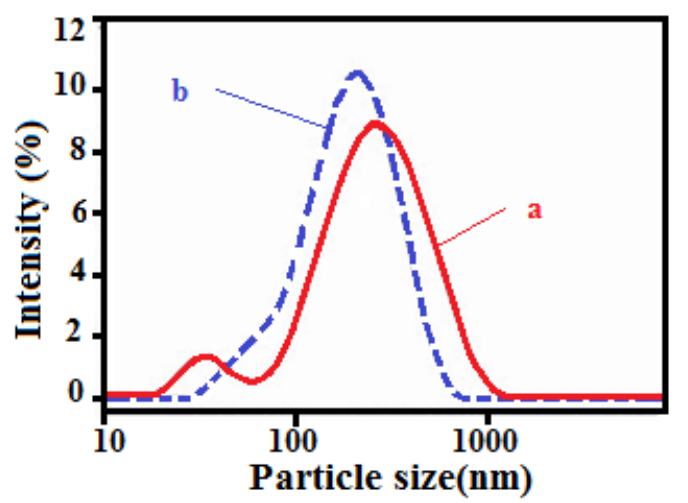

Fig. 3. Particle size distributions of Colistin-loaded liposomes obtained by a) freeze dried from t-butanol cosolvent and b) the dry film/sonication method.

Figure 4a shows the encapsulation efficiency for the antibiotic with increasing concentration of Colistin in the obtained formulation by using both methods of preparing liposomes. At concentration of $20 \mathrm{mg} / \mathrm{mL}$, there was a bit higher encapsulation part for the freeze-dried preparation.

The liposome size was similar in case of both preparation methods; the slightly greater encapsulation efficiency by the freeze dry way could not be justified by a small variation in the total encapsulation volume. 

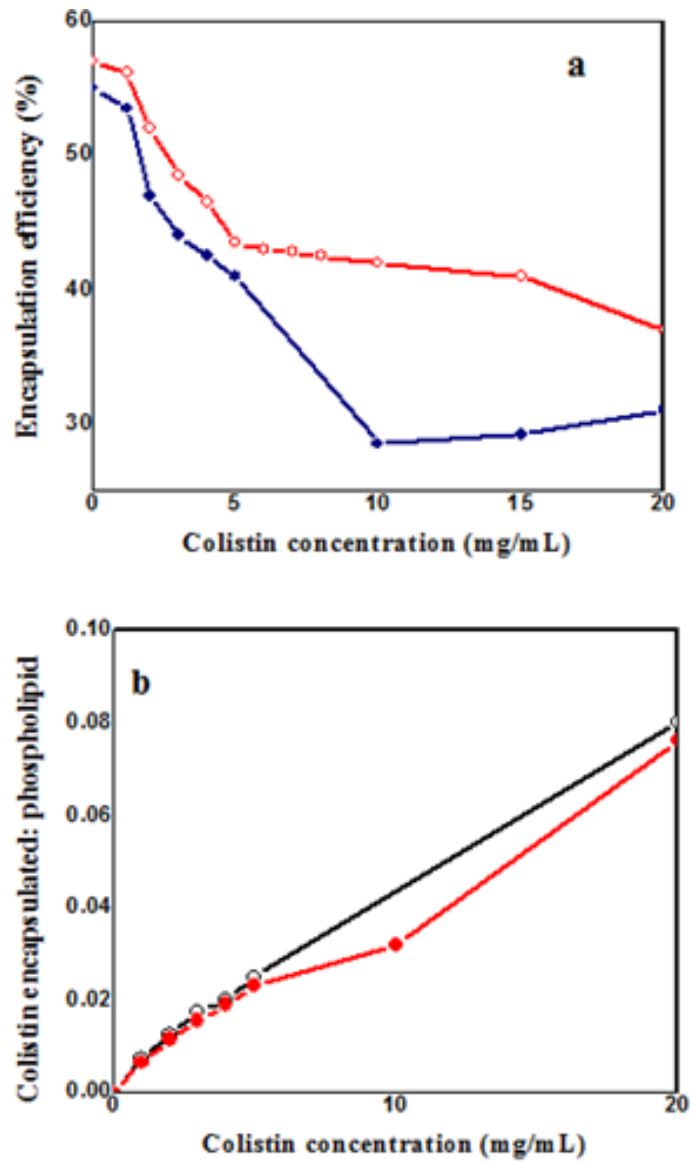

Fig. 4. Encapsulation efficiency for Colistin-loaded liposomes made by dry film (ï) and freeze drying from t-butanol (0) processes

Figure $4 \mathrm{~b}$ proves that there is a straight relationship between molar ratio of Colistin:phospholipid with increasing of drug concentrations for both preparation process.

Figure 5 demonstrates differences in encapsulation efficiencies between Colistin loaded into liposomes prepared with or without cholesterol, with rising antimicrobial agent concentration. A higher encapsulation was obtained by inclusion of cholesterol to DOPC in molar ratio of 2:1.

In vitro release of the antibiotic from liposomes is presented in figure 6. For release of Colistin from liposomes was essential to dilute the dispersion into a release medium with a significant concentration and observe the resulting antibiotic release. After $10 \mathrm{~min}$, half of drug content was free in the release medium and throughout

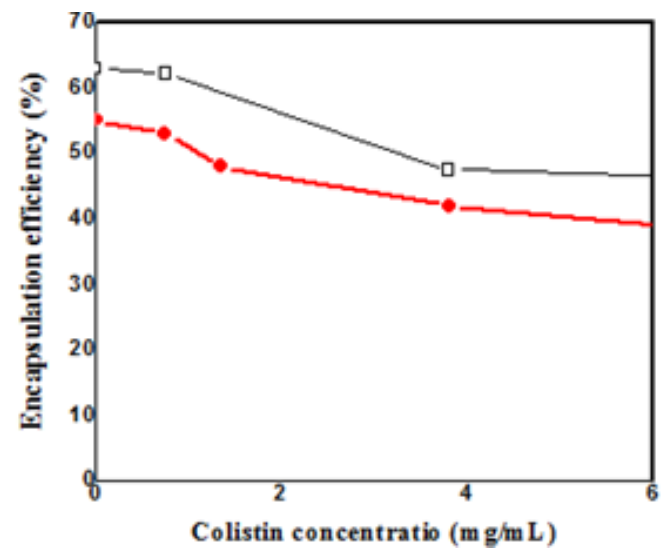

Fig. 5. Encapsulation efficiency of Colistin in liposomes made from DOPC (•) and DOPC-cholesterol 2:1 ( $\square)$

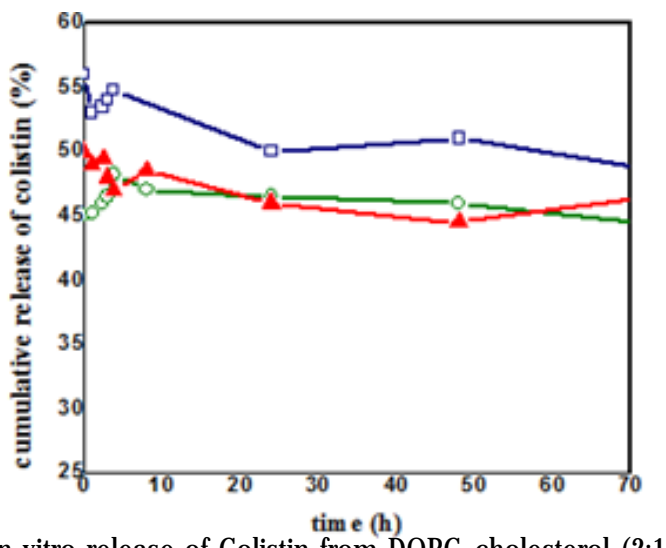

Fig. 6. In vitro release of Colistin from DOPC-cholesterol (2:1) liposomes containing $2.5(\square), 10$ ( $\Delta$ ), and $20 \mathrm{mg} / \mathrm{mL}$ (o) Colistin

the $72 \mathrm{~h}$ the equilibration of antibiotic concentration upon dilution was produced.

\section{Conclusions}

In lastfew years, the administration of Colistin for serious infections treatment caused by multi-drug resistant microorganisms increased worldwide. Due to their activity and biocompatibility, lipid nanoparticles represent an encouraging choice to the currently available therapy.

The adverse effects of the active antibiotic molecules could be reduced due to the controlled drug release. Based on sustained release of the drug and the uniform distribution through the target area, the efficacy of the antibiotic intercalated nanoparticles could be enhanced.

The results of this work revealed that Colistin loaded nanoparticles are efficient in treatment of health careassociated infections caused by multi-drug resistant pathogens.

\section{References}

1.FALAGAS, M.E., RAFAILIDIS, P.I., KASIAKOU, S.K., HATZOPOULOU, P., MICHALOPOULOS, A., Clin Microbiol Infe, 12 (12), 2006, p. 1227. 2.TAMMA, P.D., LEE, C.K., Pediatr infect Dis J , 28 (6), 2009, p. 534. 3.FALAGAS, M.E., KARAGEORGOPOULOS, D.E., Clin infect Dis, 46 (7), 2008, p. 1121

4.GOVERMAN, J., WEBER, J.M., KEANEY, T.J ., SHERIDAN, R.L., J Burn Care Res, 28(3), 2007, p. 421.

5.GISKE, C.G., MONNET, D.L., CARS, O., CARMELI, Y., Antimicrob Agents Chemother, 52(3), 2008, p. 813.

6.SOULI, M., GALANI, I., GIAMARELLOU, H., Euro Surveill, 13(47). 2008, p. 19045.

7.STEHR, S.N., REINHART, K., 39 (1), 2013, p. 3.

8.MARTIN, G.S., MANNINO, D.M., EATON, S., MOSS, M., N Engl J Med, 348, 2003, p. 1546.

9.HALL, M.J., WILLIAMS, S.N., DEFRANCES, C.J ., GOLOSINSKIY, A., NCHS Data Brief, 62, 2011, p. 1.

10.ZILBERBERG, M.D., SHORR, A.F., MICEK, S.T., VAZQUEZGUILLAMET, C., KOLLEF, M.H., Crit Care, 18, 2014, p. 596.

11.SINGER, M., DEUTSCHMAN, C.S., SEYMOUR, C.W., SHANKAR-HARI, M., ANNANE, D., BAUER, M., BELLOMO, R., BERNARD, GR., CHICHE, J.D., COOPERSMITH, C.M., HOTCHKISS, R.S., LEVY, M.M., MARSHALL, J.C., MARTIN,

12.ANTON, E., BOTNARIUC, N., ANCUTA, E., DOROFTEI, B., CIOBICA, A., ANTON, C., MEDICAL-SURGICAL JOURNAL-REVISTA MEDICO-CHIRURGICALA, 119, no. 2, 2015, p. 410.

13.DOROFTEI, B., ZLEI, M., SIMIONESCU, G., MAFTEI, R., CUMPATA, S., EMERSON, G., Reproductive Health, 12, 2015, article 38. DOI: 10.1186/s12978-015-0031-x

14.BENGHIAC, A.G., BUDACU, C., MOSCALU, M., IOAN, B.G., MOLDOVANU, A., HABA, D., ROMANIAN JOURNAL OF LEGAL MEDICINE, 25, no. 2, 2017, p. 174. 
15.DOROFTEI, B., MAMBET, C., ZLEI, M., PLOS ONE, 10, no. 4, 2015, Article Number: e0125216

16.TANTARU, G., APOSTU, M., Rev. Chim (Bucharest) , 61, no. 7, 2010, p. 632.

17.BOSINCEANU, A., PADURARU, O.M.,; VASILE, C., POPOVICI, I., TANTARU, G., OCHIUZ, L ., Farmacia, 61, no. 5, 2013, p. 856.

18.GUDRUMAN, A.D., BIBIRE, N., TANTARU, G., APOSTU, M., VIERIU, M., DORNEANU, V., Rev. Chim (Bucharest), 64, no. 4, 2010, p. 393. 19.APOSTU, M., TANTARU, G., VIERIU, M., PANAINTE, A.D., BIBIRE, N., AGOROAEI, L., Rev. Chim (Bucharest), 68, no. 4, 2017, p. 683. 20.DOLOCA, A., TANCULESCU, O., TRANDAFIR, L., CIONGRADI, I., STOLERIU, S., MOCANU, R., IFTENI, G., Materiale Plastice, 53, no. 3 , 2016, p. 370-374

21.TRANDAFIR, L.M., BACIU, G., CONSTANTIN, M.M.L., MASTALERU, A., TEMNEANU, O.R., MIHAI, B., NOVAC, O., FRASINARIU, O.E., IVAN, A., TUDORACHI, N.B., AL HIARY, R., MOSCALU, M., Rev.Chim. (Bucharest), 69, no. 11, 2018, p. 3048-3051.

22.G.S., OPAL, S.M., RUBENFELD, G.D., VAN, DER, POLL, T., VINCENT, J.L., ANGUS, D.C., JAMA, 315, 2016, p.801.

23.FERRER, R., MARTIN-LOECHES, I., PHILLIPS, G., OSBORN, T.M., TOWNSEND, S., DELLINGER, R.P., ARTIGAS, A., SCHORR, C., LEVY, M.M., Crit Care Med, 42, 2014, p.1749.

24.DANIELS, R., J Antimicrob Chemother, 66 (2), 2011, p. 11. 25.GAIESKI, D.F., MIKKELSEN, M.E., BAND, R.A., PINES, J.M., MASSONE, R., FURIA, F.F., SHOFER, F.S., GOYAL, M., Crit Care Med, 38, 2010, p. 1045.

26.MAYR, F.B., YENDE, S., ANGUS, D.C., Virulence, 5, 2014, p. 4.

27.MAYR, F.B., YENDE, S., LINDE-ZWIRBLE, W.T., PECK-PALMER, O.M., BARNATO, A.E., WEISSFELD, L.A., ANGUS, D.C., JAMA, 303, 2010, p. 2495.
28.NATION, R.L., LI, J., Curr Opin Infect Dis.,22, 2009, p. 535.

29.LI, J., NATION, R.L., TURNIDGE, J.D., MILNE, R.W., COULTHARD, K., RAYNER, C.R., PATERSON, D.L., Lancet Infect Dis., 6, 2006, p. 589. 30.MICHALOPOULOS, A., FALAGAS, M.E., Crit Care Clin., 24, 2008, p. 377.

31.VELKOV, T., THOMPSON, P.E., NATION, R.L., LI, J ., J Med Chem., 53, 2010, p.1898.

32.BALAJI, V., JEREMIAH, S.S., BALIGA, P.R., Indian J Med Microbiol., 29, 2011, p. 230 .

33.GUPTA, S., GOVIL, D., KAKAR, P.N., PRAKASH, O., ARORA, D., DAS, S., GOVIL, P., MALHOTRA, A., Indian J Crit Care Med., 13, 2009, p. 49. 34.BERGEN, P.J., LI, J., NATION, R.L., TURNIDGE, J.D., COULTHARD, K., MILNE, R.W., J Antimicrob Chemother., 61(3), 2008, p. 636.

35.TAN, C.H., LI, J., NATION, R.L., Antimicrob Agents Chemother., 51(9), 2007, p.3413.

36.PETROSILLO, N., IOANNIDOU, E., FALAGAS, M.E,. Clin Microbiol Infect., 14(9): 2008, p. 816.

37.DUDHANI, R.V., TURNIDGE, J.D., COULTHARD, K., MILNE, R.W., RAYNER, C.R., LI, J., NATION, R.L., Antimicrob Agents Chemother., 54(3), 2009, p. 1117.

38.SCHIFFELERS, R.M., STORM, G., TEN, KATE, M.T., STEARNECULLEN, L.E., DEN, HOLLANDER, J.G., VERBRUGH, H.A., BAKKERWOUDENBERG, I.A., J Liposome Res., 12(1-2), 2002, p. 121.

39.SACHETELLI, S., KHALIL, H., CHEN, T., BEAULAC, C., SENECHAL, S., LAGACE, J., Biochim Biophys Acta., 1463(2), 2000, p. 254. 40.J ONES, M.N., Methods Enzymol, 391, 2005, p. 211.

41.MEERS, P., NEVILLE, M., MALININ, V., SCOTTO, A.W., SARDARYAN, G., KURUMUNDA, R., MACKINSON, C., JAMES, G., FISHER, S., PERKINS, W.R., J Antimicrob Chemother., 61(4), 2008, p. 859.

$\overline{\text { Manuscript received: 03.09.2019 }}$ 